\title{
The Village Integrated Social Services Through the Social Welfare Center in Indonesia
}

\author{
Hari Harjanto Setiawan ${ }^{1, *}$ Setyo Sumarno ${ }^{2,}$ Alit kurniasari ${ }^{3,}$ Husmiati Yusuf $^{4}$, \\ Ruaida Murni ${ }^{5}$, Aulia Rahman ${ }^{6}$ \\ 1,2,3,4,5,6 Research and Development Center of Social Welfare Ministry of Social Affairs RI \\ *Corresponding author. Email: hari.harjanato@kemsos.go.id
}

\begin{abstract}
This study reveals an integrated social service for the poor and vulnerable at the village level through the Social Welfare Center. In Indonesia it is called Puskesos, which is a place for implementing integrated social activities between community groups in villages in the Social Welfare Development scheme. Puskesos aims to integrate various potentials and resources in the community, social networks, and build togetherness in overcoming social problems at the village level. The research method used is descriptive qualitative. This research specifically describes Puskesos as the spearhead of direct social services, namely accessibility, referrals, advocacy, and data information providers. The results showed that Puskessos can accelerate social services in helping residents identify their needs and can provide services with social programs managed by the government and the private sector. They can also quickly resolve complaints about the social programs they receive and ensure that their complaints are handled properly. Puskesos can bring social services closer to the community in the village so that they do not have to travel long distances to the district level. Citizens only need to come to one place to access various comprehensive social programs.
\end{abstract}

Keywords: Integrated, Social Services, Social Welfare Center.

\section{INTRODUCTION}

Increasing welfare and social protection for the poor and vulnerable is one of the Government's main agendas. This has been mandated in the Indonesian government's Development Plan. The requested agenda is proposed by the Central Government, Local Government, private sector, and the community. In addition, many families who need social services do not get them even though they are eligible to be recipients of social assistance. Services for social problems that are not optimal stems from an understanding that ignores cohesiveness in the handling process. Handling of social problems that is carried out based on the sectoral service paradigm has not yet led to service targets and is not carried out in a sustainable manner. Currently, social services are still running independently and there is a lack of coordination. Whereas the law requires that the implementation of social welfare be carried out in a sustainable and integrated manner.

Integrated services at the village level through Puskesos are a measure of improving community welfare in order to improve community welfare according to their characteristics[1]. One way to optimize integrated services at the village level is through Puskesos. Thus Puskesos are the spearhead of social welfare services at the lowest level because of their existence at the village level. The services provided by Puskesos include easy access to services, providing referrals, advocacy and providing data and information for beneficiaries and source systems.

This study aims to provide information about integrated services through Puskesos. This information will be answered through the following research questions: 1) How is social service integrated through Puskesos? 2) How is the Puskesos institutional? The results of this study are beneficial for the government and society to develop integrated social services at the village level.

\section{TEORETICAL FRAMEWORK}

Handling social problems in Indonesia is aimed at welfare for the community. Social welfare is defined in various perspectives, namely (1) social welfare as an 
organized activity or system, (2) as a prosperous condition, and (3) as a scientific discipline[2]. Paying attention to perspectives in defining social welfare, then social welfare is used, namely welfare as a condition of well-being. The concept of social welfare is a better condition, happiness, and prosperity which consists of three very important elements. This is in line with the opinion of Midgley that, "A condition of social welfare (or social well-being) is conceived of as comprising three elements. They are, first, the degree to which social problems are to manage. Second, the extent to which needs are met and finally, the degree to which opportunities for advancement a provided. These three elements apply to individuals, families, groups, communities, and even whole societies"[3].

Referring to the concept, then welfare is an ideal thing that everyone wants to achieve. In line with the above, the goals of social welfare are: "The goal of social welfare is to fulfill the social, financial, health, and recreational requirements of all individuals in a society. Social welfare seeks to enhance the social functioning of all age groups, both rich and poor. When other institutions in our society, such as the market economy and the family, fail at times to meet the basic needs of individuals or groups of people, then social services are needed and demanded"[4]. So welfare is the fulfillment of individual physical and spiritual needs in society.

In its development, welfare is not only in fulfilling needs but also fulfilling the rights of a citizen. Human rights are "a claim right held by individuals in virtue of the fact that they are human beings. Human rights are not tied to a particular social class, professional group, cultural collective, racial group, gender, or any other exclusive category" [5]. There are two values in human rights, namely freedom, and welfare. The welfare dimensions include: "1) Quality of life (objective living condition dan subjective well-being). 2) Social cohesion (disparities, inequalities, social exclusion dan social ties/social capital). 3) Sustainability (human capital dan natural capital) 4) Dimensions of social change (Sociodemographic and economic structure and values and attitudes)"[6].

\section{METHODOLOGY}

In general, this study aims to identify and analyze the integrated handling of social problems, through Puskesos. This research was conducted in 2019 using a qualitative approach with case studies. To describe a process of handling in detail, the approach chosen is qualitative. In this approach, researchers begin with a self-assessment and reflections about them selfs as situated in a sociohistorical context[7] with the hope of obtaining appreciation, experience, perception of understanding and giving meaning to life. A qualitative approach helps researchers in describing the characteristics of integrated social services at the village level, because "Qualitative research methods emphasize the depth of understanding associated with idiographic concern, they attempt to tap the deeper meanings of particular human experiences and are intended to generate theoretically richer observation that is not easily reduced to numbers"[8]. A qualitative approach was chosen to build an understanding of the phenomenon of integrated services at the village level through Puskesos because it is to understand social phenomena and develop new concepts [9].

Interviews were conducted through a face-to-face meeting with informants. The selection of informants was done purposively. The informant in this study is someone who knows the information needed in the research, which is about integrated services at the village level through the Puskesos. Based on these characteristics, informants who can contribute to providing data on research directly include the Chair of the Puskesos, Front office, back office, and policymakers. The location of this research was chosen purposively based on regions that had developed Puskesos throughout the region. The regions selected as case studies are Bandung Regency, Cianjur Regency, and Sumbawa Regency.

\section{RESULT AND ANALISYS}

\subsection{Result \\ 4.1.1. Case Study of Puskesos Implementation in Cianjur Regency}

The Puskesos in Cianjur District is part of the "Sijago" Integrated Service and Referral System (SLRT) that was established in 2016. Given the importance of the existence of the Puskesos in social services at the village level, the Social Service in coordination with the Regional Apparatus Organization (OPD) developed from the original 2 Puskesos into all villages establishing the Puskesos. In its development until 2019 through the regent's commitment, all 360 villages in Cianjur had established Puskesos.

Social services by the Puskesos in Cianjur Regency include; 1) Receiving complaints from residents about social programs in the village; 2) Provide information related to social services and mechanisms available; 3) Provide information about social programs both from national, provincial and district/city programs and non-government programs; 4) record the basic profile of citizens who have not been included in the Integrated Social Welfare Data (DTKS) for later checking their eligibility as a new Beneficiary; 5) Receiving complaints from residents who have been registered in the DTKS; 6) Give answers to public complaints; 6) Handling citizen complaints that can be handled at the Puskesos Secretariat; 7) Referring citizen complaints that cannot be handled at the Puskesos to other program managers both government and nongovernment programs. 
The main task and function of the Puskesos are to carry out technical tasks in the social program in implementing the provision of recommendations and clarification of data on integrated services for poverty reduction in education, health, and socio-economic fields. However, the majority of Puskesos services in the Cianjur Regency are collaborating with the Health Office in arranging BPJS Cards. At present institutionally, the Regents already have Regulations governing the Puskesos.

\subsubsection{Case Study of Puskesos Implementation in Bandung Regency}

Puskesos in Bandung Regency are part of the "Sabilulungan" Integrated Service Referral System at the district level. A service system that helps meet the needs of the poor to increase funding and poverty alleviation implemented by the central, provincial and district/ city governments according to their needs.

Puskesos ensure that people who do not have access to social protection and services can get it. Currently in Bandung Regency has 270 Puskesos which are integrated services at the village level and 10 in the urban village so that the total number is 280 . Puskesos was established in 2016 to provide services in the form of social service recommendations, provide information on social protection and handling poverty, record the profile of residents who have not yet entered the DTKS, receive complaints from residents who enter DTKS, provide certainty of the resolution of complaints, handling residents complaints, and make a referral.

Problems commonly received by Puskesos officers include complaints about the Smart Indonesia Program, the Healthy Indonesia and Literature Program, and socio-economic issues. Activities in socializing the Puskesos are done through counseling, brochures, social media, leaflets, banners, banners, information boards, and through informal visits to the community.

\subsubsection{Case Study of Puskesos Implementation in Sumbawa Regency}

Sumbawa Regency consists of 24 districts, 8 villages, and 157 villages. In 2016, Sumbawa Regency received a program to establish an Integrated Service and Referral System (SLRT) and Puskesos by the Ministry of Social Affairs. Sumbawa Regency SLRT is known as "Sabalong Samalewa". Sabalong Samalewa is the motto of the Sumbawa Regency which has the meaning of building in a balanced and harmonious manner between material physical development and mental and spiritual development. Sumbawa Regent Regulation Number 105 the Year 2017 concerning the "Sabalong Samalewa" Poverty Reduction and Referral System.
Two Puskesos that were built with the State Budget, namely Setuwe Berang Village at Utan District and Berare Village at Moyo Hilir District. Besides, there were 53 Independent Puskesos built using the local budget and approved through the Decree of the Regent of Sumbawa Number 009/792/2018 regarding the Establishment of the Puskesos. The village government that owns the Puskesos also provides a budget of Rp. 1 million per year to support the Puskesos activities. Innovation services made by Sumbawa Regency are known as population administration services for the poor which have been strengthened by a cooperation agreement with the Department of Population and Civil Registration, this innovation received an award from the Ministry of Social Affairs in 2018.

\subsection{Analisys \\ 4.2.1. Integrated Social Services}

Development in Indonesia has so far focused on economic growth, whereas economic growth has not always been followed by equal distribution of income for all residents. So that there is an imbalance in people's lives that has the potential to cause social problems[10]. Handling of social problems through Puskesos must be participatory with all elements of society. Puskesos is a forum that brings together beneficiaries and the source system in the community itself. Thus, solving social problems is not only the responsibility of the government but also the responsibility of all elements of society[11].

Social problems will not be resolved if the government is there, so that an integrated party is needed to handle it. The government needs to invite public and private individuals to deal with these problems. All that is not necessary coordination and coordination so that all the existing potentials and resources do not work independently. The three of them also have the same position and should not feel the greatest. Everything has advantages and disadvantages, so that the synergistic bias will be a tremendous force to solve existing social problems. Thus the empowerment process will run well because all lead to the same goal, namely the community that is able to solve social problems itself. Puskesos will bring together all elements in society to jointly solve social problems[12].

Policies on social issues are just routine and unsustainable. This needs evaluation and includes elements of empowerment so that the program is sustainable. Evaluation is needed so that there are changes for the better in the future[13]. In dealing with social program problems, social assistants who have good competence are needed. Social assistant is needed to connect technical problems with bureaucratic problems that must be achieved[14]. Social problems, 
especially poverty, are not only an economic approach, but require other approaches. The causes of social problems are very complex so that the interaction of various elements in society is needed[15]. Physical and social development programs will be more successful than economic development alone[16].

\subsubsection{Puskesos Institutional}

The role of Puskesos in solving social problems at the village level is emphasized in Law No. 11 of 2009. Furthermore, it is revealed in Government Regulation

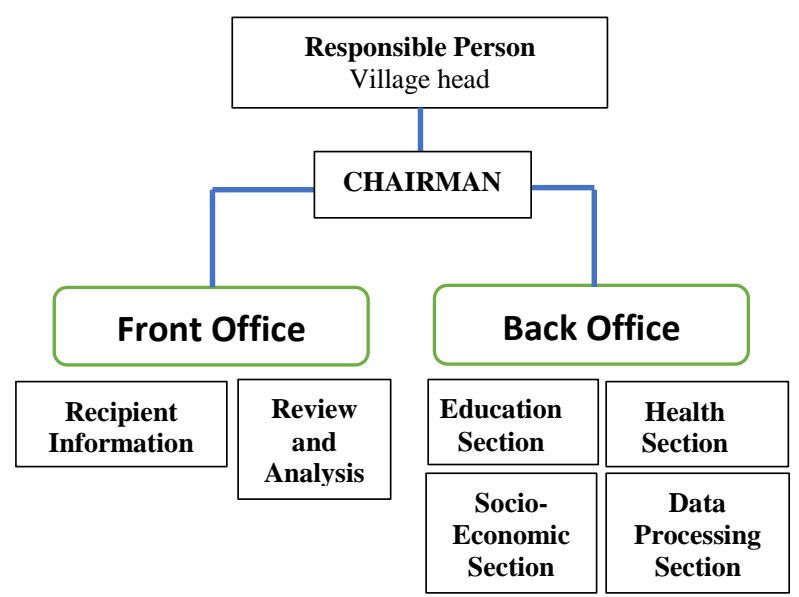

Figure 1 Organizational Structure of the Puskesos

Puskesos has the task of integrating government, individual and private programs in providing services to the community. The services provided are to avoid overlapping and equal distribution. Puskesos have main functions, among others: data and information center on social issues, social service center, referral center and social advocacy center for residents.

\section{CONCLUSION}

Puskesos are the meeting place between elements in society in an integrated manner in solving social problems at the village level. Puskesos brings together social problems and the source system that exists in the community. Puskesos need to be formed to make it easier for the community to identify problems and services needed to solve social problems. The community can also complain directly against the services provided and get certainty that these problems will have an impact. Thus, Puskesos can shorten the service bureaucracy for the community.

Based on the study on Puskesos above, there are several recommendations as follows; First, Puskesos need to build cooperation in reaching potential and resources in the community to overcome social problems. So it must reach the beneficiaries and connect with the required source system. Second, as an institution, the Ministry of Social Affairs is expected to
No. 39 of 2012, article 44 that: "The Social Welfare Center is a place that functions to carry out synergistic and integrated social service activities between community groups in the community in the village or the urban village in the implementation of social welfare ". The next article, namely article 45 "Minimum standards for facilities and infrastructure of social welfare centers includes a place that is used as a center for joint activities, service personnel consisting of management and implementing personnel, and equipment consisting of office support equipment and technical service support equipment. " The institutional structure of Puskesos is as follows:

be able to establish a mutual agreement, particularly with the Ministry of Home Affairs and the Ministry of Villages in developing Puskesos in each region.

\section{ACKNOWLEDGMENTS}

This research was funded by the research and development center of Social Welfare, Ministry of Social Affairs of the Republic of Indonesia in 2019. In this study all authors were the main contributors where the team was involved in collecting data and discussing the results together.

\section{REFERENCES}

[1] Muhtar and I. Huruswati, "Pelayanan Satu Pintu Penanggulangan Kemiskinan di Kabupaten Sragen," Sosio Konsepsia, vol. 1, pp. 1-25, 2015.

[2] I. R. Adi, Intervensi Komunitas dan Pengembangan Masyarakat: Sebagai upaya pemberdayaan masyarakat. Jakarta: PT RajaGrafindo Persada, 2012.

[3] J. Midgley, Social Development, The Developmental Perspektive In Social Welfare. London: SAGE Publications, 1995.

[4] C. Zastrow, Introduction to Social Work and Social Welfare: Empowering People, 10th ed. Brooks/Cole Cengage Learning, 2010.

[5] T. Ward and A. Birgden, "Human Rights and Correctional Cinical Prctice," Aggress. Violent Behav., vol. 12, pp. 628-643, 2007.

[6] H.-H. Noll, The European System of Social Indicators : A Tool for Welfare Measurement and Monitoring Social Change, Workshop on Measurement of Wellbeing in Developing Countries Hanse Kolleg, Delmenhorst. 2004.

[7] W. L. Neuman, Social Research Methods: Qualitative and Quantitative Approach. Boston, 2006.

[8] A. Rubin and E. Babby, Research Methods for Social Work. Brooks/Cole Cengage Learning, 2007.

[9] M. Alston and W. Bowles, Research For Social Workers: An Introduction to Methods. Australia: Allen and Unwin, 1998.

[10] N. Prawoto, "Memahami Kemiskinan Dan 
Strategi Penanggulangannya," J. Ekon. Stud. Pembangunan., vol. 9, no. 1, pp. 56-68, 2008, doi: 10.18196/jesp.9.1.1530.

[11] I. G. W. M. Yasa, "Penanggulangan Kemiskinan Berbasis Partisipasi Masyarakat Di Provinsi Bali,” Ekon. dan Sos., pp. 86-91, 2008, [Online]. Available:

https://ojs.unud.ac.id/index.php/input/article/vie w/3187.

[12] R. E. Putera, “Analisis terhadap Program-program Penanggulangan Kemiskinan dan Pemberdayaan Masyarakat di Indonesia," J. Demokr., vol. 6, no. 1, 2007.

[13] A. Fatony, "Kebijakan Pengentasan Kemiskinan Berbasis Participatory Poverty Assessment: Kasus Yogyakarta," Sosio Konsepsia, pp. 123142, 2017, doi: 10.33007/ska.v16i2.798.
[14] I. Murdiansyah, "Evaluasi Program Pengentasan Kemiskinan Berbasis Pemberdayaan Masyarakat ( Studi Kasus Pada Program Gerdu-Taskin di Kabupaten Malang )," J. WIGA, vol. 4, no. 1, pp. 71-92, 2014.

[15] T. Utami, "Pemberdayaan komunitas sektor informal Pedagang Kaki Lima (PKL), Suatu alternatif penanggulangan kemiskinan,” J. Sosiol. Dilema, vol. 25, no. 2, pp. 114-123, 2010.

[16] A. Taufiq, D. Erowati, and Wijayanto, "Upaya Penanggulangan Kemiskinan Berbasis Pemberdayaan Masyarakat Lokal (Belajar dari Pelaksanaan Program Penanggulangan Kemiskinan Perkotaan di Kelurahan Bintoro, Kecamatan Demak, Kabupaten Demak)," Polit. J. Ilmu Polit., vol. 1, no. 1, 2010. 